\title{
Cancer Electrogene Therapy with Interleukin-12
}

\author{
Maja Cemazar ${ }^{1,2, *}$, Tomaz $\mathrm{Jarm}^{3}$ and Gregor Sersa ${ }^{1}$
}

${ }^{I}$ Department of Experimental Oncology, Institute of Oncology Ljubljana, Zaloska 2, SI-1000 Ljubljana, Slovenia,
${ }^{2}$ University of Primorska, College of Health Care Isola, Polje 42, SI-6310 Isola, Slovenia, ${ }^{3}$ University of Ljubljana,
Faculty of Electrical Engineering, Trzaska 25, SI-1000 Ljubljana, Slovenia

\begin{abstract}
Electrogene therapy combines administration of plasmid DNA into tissue followed by local application of electric pulses. In electrogene therapy with interleukin-12 (IL-12), different routes of administration, different doses of plasmid DNA and different protocols for delivery of electric pulses were evaluated in numerous preclinical studies. Antitumor effectiveness was tested in different types of primary tumors, distantly growing tumors and induced metastases. Intratumoral $I L-12$ electrogene therapy has been proved to be very effective in local tumor control, having also a systemic effect. Intramuscular and peritumoral $I L-12$ electrogene therapy had also a pronounced systemic effect and when combined with other treatment strategies resulted in tumor cures. Antitumor effectiveness of $I L-12$ electrogene therapy is due to the induction of adaptive immunity and innate resistance and anti-angiogenic action. Translation of preclinical studies into clinical trials in human and veterinary oncology has started with encouraging results that would hopefully lead to further investigation of this therapy, also in combination with other cancer treatment modalities.
\end{abstract}

Keywords: Interleukin-12, electroporation, electrogene therapy, gene electrotransfer, clinical studies, melanoma.

\section{INTRODUCTION}

Interleukin-12 (IL-12) is a soluble cytokine that is produced by phagocytes and dendritic cells in response to pathogens, activated $\mathrm{T}$ cells and component of inflammatory extracellular matrix [1]. IL-12 was discovered in 1989. It was isolated from the phorbol diester-induced Epstein-Barr virustransformed human B lymphoblastoid cell line RPMI 8866 and was named "natural killer cell stimulatory factor" [2]. In this first paper, the three activities of IL-12 were already recognized; induction of IFN- $\gamma$ production, augmentation of NK cell-mediated cytotoxicity and enhancement of mitogenic response of $\mathrm{T}$ cells. It was also determined that the protein is a heterodimer composed of two subunits, a $35 \mathrm{kDa}$ light chain (also known as p35 or IL-12 $\alpha$ ), and a $40 \mathrm{kDa}$ heavy chain (known as p40 or IL-12ß). Just one year later, an independent discovery of the "cytotoxic lymphocyte maturation factor" was published and in 1991 it was proposed that this newly discovered cytokine should be given the designation IL-12 [3, 4]. Shortly thereafter, human and murine genes for IL-12 were cloned and this stimulated further studies on the therapeutic efficacy of recombinant IL-12 in different tumor models including metastases [5, 6]. IL-12 antitumor effectiveness is multifactorial and is still not fully elucidated. Briefly, it consists of induction of IFN- $\gamma$ production that induces infiltration of $\mathrm{CD}^{+} \mathrm{T}$ lymphocytes and NK cells into tumors, which exhibit cytolytic activities. In addition, IL-12 has antiangiogenic action through activation of IFN- $\gamma$ induction of interferon inducible protein-10 (IP10) and monokine Mig induced by IFN- $\gamma$. Furthermore, IL-12 augments the $\mathrm{CD} 4^{+}$Th1 response, leading to activation of a specific B cell response. IL-12's potent antitumor and antimetastatic

*Address correspondence to this author at the Institute of Oncology, Zaloska 2, SI-1000 Ljubljana, Slovenia; Tel: +386-1-5879544;

Fax: +386-1-15879434; E-mail: mcemazar@onko-i.si activity was shown on many preclinical tumor models $[1,7-$ 17]. Preclinical studies encouraged clinical trials, where the safety and antitumor efficacy of recombinant human IL-12 (rh-IL-12) were examined [18-25]. The first clinical phase I escalation study on patients with different malignancies was published only 8 years after discovery of IL-12 [18]. Mainly patients with renal carcinoma and melanoma were included. They were treated with intravenously injected human recombinant IL-12. Only a minor tumor response was obtained; one transient complete response in a melanoma patient and a partial response in a renal carcinoma patient. Unfortunately, the first reports of phase I and II clinical trials demonstrated toxic side-effects of recombinant human IL-12 protein at doses which barely resulted in any antitumor effectiveness [26]. In the most effective study, treatment with rhIL-12 resulted in a partial or complete response in $56 \%$ of patients with cutaneous T-cell lymphoma [25].

Gene therapy introduced an advanced route of administration and improved action of IL-12. Recent studies have evaluated the antitumor effectiveness and safety of intratumoral $I L-12$ gene therapy. The delivery systems for $I L-12$ gene therapy are various and include transfer of naked plasmid DNA alone [27, 28], adenoviral [29-33] or other viral vectors [34-36], as well as gene gun [37, 38], electroporation [39-42] and other non-viral vectors [43, 44]. Clinical studies in human and also in veterinary oncology were initiated and the first results showed that $I L-12$ gene therapy is a safe treatment with some beneficial clinical effect [28, 45-55].

As mentioned, IL-12 is a very potent cytokine with diverse biological activities. It has profound antitumor efficacy that was demonstrated on a variety of different types of tumors and metastases in preclinical as well as clinical studies. In recent years, several excellent reviews describing the activities of IL-12, the preclinical and clinical use of recombi- 
nant IL-12 and gene therapy with $I L-12$ have been published $[1,8,11,45,56,57]$. On the other hand, 10 years have passed since the first paper on combination of plasmid DNA encoding for IL-12 injected intramuscularly with electroporation was published [39]. There are also several reviews describing the basics of electroporation as well as its clinical use in electrochemotherapy and electrogene therapy [58-62]. Therefore, the aim of this review is to wrap-up studies on electrogene therapy with $I L-12$ that culminated in the first published clinical study of electrogene therapy with $I L-12$ for treatment of subcutaneous melanoma metastases [46] and therefore this therapy shows great promise to further translate this therapy into human and veterinary oncology.

\section{PRECLINICAL STUDIES WITH IL-12 ELECTRO- GENE THERAPY}

The use of electroporation for transfection of cells dates back to 1982, when Neumann et al. demonstrated increased uptake of plasmid DNA into mouse lyoma cells using electroporation with a high-intensity electric field [63]. They demonstrated that when linear or circular plasmid DNA containing the herpes simplex thymidine kinase $(T K)$ gene was added to a suspension of mouse $\mathrm{L}$ cells deficient in the $T K$ gene and the cells were then exposed to electric fields, stable transformants were formed that survived in the HAT selection medium. After this first demonstration that electroporation can be used for delivery of plasmid DNA, the method gained a lot of attention since it represented a promising alternative to viral and chemical methods for introduction of genes of interest into cells. Gene electrotransfer to tissues was introduced by Titomirov et al. in 1991. The skin of newborn mice was transfected with plasmid DNA. The skin was then excised and NEO-resistant colonies were found in primary cell cultures obtained from the treated skin [64]. After this first study, the use of gene electrotransfer to tissues grew rapidly. Optimization studies aiming to optimize the parameters of electric pulses for application of gene electrotransfer to different tissues, as well as studies dealing with the therapeutic effect of gene electrotransfer were performed. Therapeutic applications of gene electrotransfer were focused mainly on two fields: DNA vaccination against infectious disease, and cancer gene therapy $[65,66]$. The first use of electrogene therapy (a term used to describe gene therapy in which transfection of cells is achieved by means of electroporation) for treatment of cancer was published in 1999. Niu et al. demonstrated, that electrotransfer of a Stat 3 variant with dominant-negative properties to melanoma subcutaneous tumors induced in C57B1/6 mice suppressed the growth of transfected tumors by inducing apoptotic cell death [65]. Protection against the lethal influenza virus was achieved by intramuscular electrotransfer of plasmid DNA encoding for neuraminidase from different subtype-A viruses [66].

The first evaluation of the effects of combined use of IL12 and electroporation involved the delivery of plasmid DNA encoding $I L-12(50 \mu \mathrm{g})$ by electrotransfer to skin. Local transfection of skin of BalbC mice resulted in increased serum concentration of interferon- $\gamma$ (IFN- $\gamma$ ), whose production and secretion is induced by the presence of IL-12. The serum concentration of IFN- $\gamma$ reached a peak of $\sim 50 \mathrm{pg} / \mathrm{ml}$ two days after treatment. The electric pulse parameters that were used for skin electrotransfection with IL-12 plasmid
DNA were the same as the ones used in electrochemotherapy protocols: 8 pulses, duration $100 \mu \mathrm{s}$, amplitude $1200 \mathrm{~V}$, interelectrode distance $8 \mathrm{~mm}$. In this study, besides an electric pulse protocol consisting of high voltage pulses of short duration $(1500 \mathrm{~V} / \mathrm{cm}$ voltage over interelectrode distance, 100 $\mu$ s duration), another protocol consisting of low voltage pulses of longer duration $(100 \mathrm{~V} / \mathrm{cm}, 20 \mathrm{~ms}$ duration) was also tested [39]. Higher transfection efficiency was obtained in the skin with high voltage electric pulses of short duration. Later that year, the same group reported that electrotransfection of $I L-12$ plasmid DNA to mouse muscle resulted in systemically measurable IL-12 and IFN- $\gamma$. The serum concentration of IL-12 reached a peak 4 days post-transfection $(\sim 150$ $\mathrm{pg} / \mathrm{ml}$ ) and returned to baseline values $\sim 3$ weeks after the treatment. The peak of IFN- $\gamma$ concentration lagged behind that of IL-12 and was reached $\sim 1$ week after electrotransfer $(\sim 250 \mathrm{pg} / \mathrm{ml})$ and returned to an almost baseline level $\sim 3$ weeks after treatment [67]. Serum concentrations of IFN- $\gamma$ after gene electrotransfer in muscles were 5 times higher than after electrotransfer in skin. Interestingly, for electrotransfer in muscles, low voltage electric pulses of longer duration $(100 \mathrm{~V} / \mathrm{cm}$ voltage over interelectrode distance, $20 \mathrm{~ms}$ duration) proved to be more effective and resulted in a higher level of gene expression and in long-term expression (at least 3 weeks post-transfection) [67]. These first two studies were performed on healthy, non-tumor bearing mice and provided evidence that $I L-12$ electrotransfer to skin and muscle is an efficient delivery method which results in an increased systemic concentration of IL-12 and its effector molecule IFN- $\gamma$, and that it could be further used in immunotherapy protocols.

The first $I L-12$ electrogene therapy study demonstrating antitumor effectiveness was performed by intratumoral injection of $I L-12$ plasmid DNA $(100 \mu \mathrm{g})$ followed by application of 10 electric pulses of $150 \mathrm{~V}$ amplitude (4 $\mathrm{mm}$ interelectrode distance) and $50 \mathrm{~ms}$ duration [68]. The growth of treated mouse hepatocellular carcinoma was significantly inhibited. In addition, the growth of distant non-treated tumors was also reduced, but to a lesser extent. Furthermore, development of spontaneous lung metastases was inhibited in mice treated with $I L-12$ electrogene therapy. The mechanicsms of antitumor effectiveness of intratumoral $I L-12$ electrogene therapy were evaluated and were found to be the same as indicated for other types of therapy involving the use of IL-12: increased IL-12 and IFN- $\gamma$ serum levels, tumor infiltration of $\mathrm{NK}$ and $\mathrm{CD}^{+} \mathrm{T}$ cells and reduced microvascular density [68]. The peak in IL-12 serum concentration of 450 $\mathrm{ng} / \mathrm{ml}$ was reached 5 days after treatment, while the peak in IFN- $\gamma$ concentration of $100 \mathrm{pg} / \mathrm{ml}$ was reached on day 7 . Compared to studies performed by Heller et al., higher serum concentrations of IL-12 were achieved, while the concentrations of IFN- $\gamma$ were in a similar range. The reason for the observed differences in IL-12 concentrations probably lies in the different plasmid concentrations injected as well as in transfection of different tissues (skin, muscle, and tumor). It seems that higher concentrations of IL-12 do not reflect in increased IFN- $\gamma$ levels, demonstrating a saturation effect. Another $I L-12$ electrogene therapy was preformed on a mouse squamous cell carcinoma (SCCVII) [42]. In this study, intramuscular $I L-12$ electrotransfer was performed with a low dose of plasmid DNA $(10 \mu \mathrm{g})$ and only 2 electric 
pulses of $20 \mathrm{~ms}$ duration at $375 \mathrm{~V} / \mathrm{cm}$ (voltage over interelectrode distance). Similarly to previous studies, increased serum levels of IL-12 and IFN- $\gamma$ were obtained. However, the inhibition of growth of the established tumor was smaller than in previous studies. The authors also tested the prevention of tumor growth by electrogene therapy with $I L-12$ first performed on the same day as when the SCCVII were inoculated and then repeated three more times at one-week intervals after inoculation. Tumors did not develop in $40 \%$ of treated animals, thus demonstrating that electrogene therapy with $I L-12$ has an effect on the establishment of tumors [42]. In the same year, other researchers performed $I L-12$ electrogene therapy in mouse melanoma B16 tumors [40, 41] demonstrating that $I L-12$ electrogene therapy is also effective on a melanoma tumor model, resulting in significantly prolonged tumor growth delay. In addition, $I L-12$ electrotransfer was compared to adenoviral delivery by measuring tumor and serum levels of IL-12. Tumor IL-12 levels were comparable, while serum concentrations of IL-12 were much higher after adenoviral delivery. Furthermore, apparent toxicity of adenoviral $I L-12$ delivery was observed, which was demonstrated by animal weight loss, apathy and splenomegaly. Although the authors did not compare the antitumor effectiveness of the two different delivery methods for $I L-12$, they concluded that $I L-12$ electrogene therapy has great therapeutic potential as it results in a high local cytokine concentration without systemic increase which could lead to systemic toxicity also observed in adenoviral IL-12 gene therapy [41]. Another study performed on B16 melanoma compared the antitumor effectiveness of IL-12 gene therapies performed either intratumorally or intramuscularly [69]. The intratumoral IL-12 electrogene therapy resulted in better antitumor effectiveness than the intramuscular IL-12 electrogene therapy. In this study, $47 \%$ of mice were cured after intratumoral electrogene therapy, while in previous studies on electrogene therapy with IL-12 performed on a melanoma B16 tumor model, no tumor cures were obtained. This discrepancy is most probably due to different electric pulses used in these studies (high voltage microsecond pulses compared to low voltage millisecond pulses) and also to the different promoters used. Both, Lohr et al. and Lucas et al. used the CMV promoter that can be methylated and thus inactivated, thus leading to downregulation of downstream genes in in vivo conditions [70]. However, they used different electric pulse parameters. Kishida et al. used a CMV immediate enhancer/ $\beta$-actin $(\mathrm{CAG})$ promoter that was shown to lead to sustained expression [71], but they used electric pulses of very low amplitude $(50 \mathrm{~V})$. In a recent study, a detailed evaluation of different electric pulse parameters was done on B16 melanoma. In this study, it was demonstrated that both electropermeabilization and electrophoresis are involved in gene electrotransfer [72]. Therefore, one can speculate that low antitumor effectiveness obtained in studies of Lohr et al. and Kishida et al. was due to low transfection efficiency as they used a small number of electric pulses that produce an electrophoretic force on DNA without sufficient electropermeabilization. On the other hand, Lucas et al. used electric pulses that mainly produce electropermeabilization [40, 69]. In the case of B16 melanoma that have a soft consistency with large cells and minimal content of the extracellular matrix [73], high voltage electric pulses of microsecond duration resulted in better transfection efficiency compared to electrophoretic electric pulses, therefore leading to better antitumor effectiveness. Furthermore, Lucas et al. demonstrated that intratumoral $I L-12$ electrogene therapy leads to high local IL-12 and IFN- $\gamma$ levels, tumor infiltration of lymphocytes and a reduced number of vessels in the tumors. On the other hand, intramuscular $I L-12$ electrogene therapy resulted in increased IL-12 and IFN- $\gamma$ levels in serum but not in tumors and no tumor cures were obtained. In addition, the effects on tumor vascularity and $\mathrm{CD}^{+}$and $\mathrm{CD}^{+} \mathrm{T}$ lymphocytes were less pronounced compared to intratumoral gene therapy [69]. In the same study, intratumoral $I L-12$ electrogene therapy was also performed in athymic nude mice, which lack $\mathrm{T}$ lymphocytes. The antitumor effect was minimal compared to pertinent control groups, demonstrating a pivotal role of $\mathrm{T}$ lymphocytes in antitumor effectiveness of $I L-12$ electrogene therapy. The observed minimal antitumor effect in nude mice could be due to either antiangiogenic properties of IL-12 or to its effect on stimulation of NK cells and the humoral immune response, but this was not elucidated in the study. It is important to note that the immunocompetent mice which were cured were challenged with B16 tumor cells and $71 \%$ of mice did not develop tumors for 100 days, thus demonstrating that antitumor immunity was developed following $I L-12$ electrogene therapy [69]. Antitumor immunity was also demonstrated in another study on effectiveness, where intratumoral $I L-12$ electrogene therapy was performed 3 times and resulted in $80 \%$ of tumor cures [74]. These mice were rechallenged with tumor cells and none of them developed a tumor. In addition, it was demonstrated that intratumoral gene therapy has an effect on growth of distant tumors which were induced on the day of treatment of the primary tumors - tumors did not develop in $56 \%$ of mice. Furthermore, the occurrence of induced lung metastases was also reduced by intramuscular treatment on the day of intravenously injected B16 tumor cells and repeated on day 4 post-tumor cell injection. Only $37.5 \%$ of treated mice developed lung metastases [74]. However, the effect of intratumoral $I L-12$ electrogene therapy on development of lung metastases was not evaluated.

The antitumor effectiveness of intratumoral $I L-12$ electrogene therapy was demonstrated also in other types of cancer, such as colon carcinoma, renal cancer, lymphoma, breast carcinoma and sarcoma mouse tumor models [75-80]. Treatment of CT26 colon carcinoma tumors with 3 times repeated intratumoral $I L-12$ electrogene therapy resulted in significant inhibition of tumor growth. However, no tumor cures were observed. Prolonged therapy ( 7 times every two days) resulted in $80 \%$ tumor cures. Rechallenge of the 4 cured mice with tumor cells was performed 50 days after therapy. Tumors in rechallenged mice grew slower compared to naïve mice and in one mouse no tumor developed, demonstrating that these mice developed antitumor immunity. In the same study, subcutaneous renal carcinomas were treated with intratumoral $I L-12$ electrogene therapy. Tumors were treated twice at a 1-week interval and significant antitumor effectiveness was achieved [75], but no tumor cures were obtained. Lee et al. evaluated intramuscular $I L-12$ electrogene therapy on three different subcutaneous tumor models, lymphoma 38C13, colon carcinoma CT-26 and melanoma $\mathrm{B} 16 \mathrm{~F} 1$ only three days after tumor inoculation. Intramuscular $I L-12$ electrogene therapy was very effective in these 
small tumors. The most pronounced effect was on lymphoma tumors with $\sim 70 \%$ tumor cures, followed by CT-26 colon carcinoma with $\sim 55 \%$ tumor cures, while no tumor cures were obtained in B16F1 melanoma, which confirmed the study of Lucas et al. [69, 76]. However, intramuscular $I L-12$ electrogene therapy was less effective for treatment of induced lung metastases of B16F1 and CT-26 tumors, resulting in a reduced number and size of metastases compared to control groups but without eradication of metastases. Although the authors did not address this difference in antitumor effectiveness, one can speculate that intravenously injected tumor cells that colonize the lungs have a better vascular supply and can thus seed and grow quicker compared to tumor cells that are injected into subcutaneous tissue. Therefore, the IL-12-induced antitumor mechanisms attack a smaller number of tumor cells in the case of subcutaneous tumors as opposed to lung metastases. This notion is also supported by a study by Lucas et al., who treated induced lung metastases of B16 tumor cells on the same day and demonstrated that $37.5 \%$ of mice did not develop metastases [74]. Furthermore, Tevz et al. showed in a different tumor model, SA-1 sarcoma, that prophylactic treatment with intramuscular $I L-12$ electrogene therapy (1 day before injection of tumor cells) resulted in a $90 \%$ reduction of lung metastases, while treatment $24 \mathrm{~h}$ after intravenous injection of tumor cells resulted in only a minor effect $(30 \%$ reduction compared to control untreated group) [78]. In the same study, 3 times repeated intramuscular $I L-12$ electrotransfer resulted in 27\% SA-1 and 14\% LPB subcutaneous sarcoma tumor cures. The effects of peritumoral and intratumoral $I L$ 12 electrogene therapy were compared on the same tumor model, the SA-1 sarcoma [79]. This was the first study which addressed the antitumor effectiveness of $I L-12$ electrogene therapy applied to skin in the vicinity of established tumors - peritumoral electrogene therapy. As expected, the intratumoral $I L-12$ electrogene therapy resulted in better antitumor effectiveness in this tumor model (it produced 90$100 \%$ tumor cures) than peritumoral therapy. This direct antitumor effectiveness was even better than in the reports on the effectiveness of $I L-12$ gene therapies employing either viral or non-viral gene delivery methods [54, 81, 82]. Peritumoral $I L-12$ electrogene therapy resulted in $16 \%$ tumor cures with a significant growth delay of the remaining tumors, which is comparable to the effect after 3 times repeated intramuscular therapy [78]. Furthermore, both intratumoral and peritumoral therapies resulted in a detectable increase in tumor and serum IL-12 and IFN- $\gamma$ levels that did not differ between the routes of administration. In line with these results, the growth of distant untreated tumors was delayed to the same degree regardless of the therapy used. As shown with other tumor models, the animals that were rechallenged with SA-1 tumor cells after intratumoral $I L-12$ electrogene therapy did not develop tumors in $61 \%$ of cases [79]. The pronounced antitumor effectiveness of the studies on sarcomas can be ascribed to several facts. One is that the SA-1 tumor model is highly immunogenic [83] and the other is that electric pulse parameters used in these studies were optimized for tumors, muscles and skin respectively [72, 84, $85]$, and therefore high transfection efficiencies were obtained that translated in pronounced antitumor effectiveness. Another tumor model breast adenocarcinoma BJMC3879, was treated with intratumoral $I L-12$ electrogene therapy per- formed once a week for 8 weeks. The treatment resulted in significant subcutaneous tumor growth delay and in reduction of lymph node and lung metastases [77].

Most of the studies of $I L-12$ electrogene therapy were performed in mice. Recently, two studies were published that evaluated gene transfer of $I L-12$ in beagle dogs. Pavlin et al. evaluated different electric pulse parameters for intramuscular gene transfer to determine an effective protocol for further clinical use. Besides reporter gene (green fluorescent protein) to determine local transfection efficiency, IL-12 was also used to determine whether intramuscular gene electrotransfer results in a systemically measurable increase in IL12 and IFN- $\gamma$. Electric pulse protocols that resulted in the highest local transfection (tested with reporter gene expression) were tested with $I L-12$ gene electrotransfer. The serum level of IL-12 was increased in only one dog (out of 6), while IFN- $\gamma$ levels were increased in half of the treated dogs. Blood biochemistry values were all within the reference values up to 4 weeks after electrotransfer to muscles. The only side- effect that was observed and was connected to the therapy was tissue swelling at the site of electroporation, but was only transitory [86]. Another study on beagle dogs evaluated the effectiveness of intratumoral $I L-12$ electrogene therapy on a transplantable canine transmissible venereal tumor. Significant growth inhibition was observed which even led to complete responses. In addition, a systemic antitumor effect was achieved that prevented growth of new tumors and cured an established tumor grown at a distant site [87].

In summary, preclinical studies of $I L-12$ electrogene therapy have proved that this therapy is a feasible and effective approach to treatment of established tumors and metastases of many different histologies. Furthermore, rechallenge experiments demonstrate that antitumor immunity developed after $I L-12$ electrogene therapy. Variability in tumor response can be ascribed to different models used in the studies, to different route of plasmid DNA administration (intratumoral, peritumoral, intramuscular), different doses of plasmid DNA and also to different electric parameters as well as different electrode designs. Overall, intratumoral $I L-12$ electrogene therapy was the most effective treatment, followed by intramuscular and peritumoral administration. The intratumoral route of administration produced a high level of IL12 and IFN- $\gamma$ in tumors with minimal or no increase in serum IL-12 and IFN- $\gamma$ levels. Systemic toxicity was not observed in any of the studies. A comprehensive toxicity evaluation was performed after intratumoral $I L-12$ electrogene therapy in B16 melanoma tumor-bearing mice [88]. No significant toxic effects were observed in animals treated with $I L-12$ intratumoral electrogene therapy and the only histopathological abnormality found in these mice 30 days after treatment was inflammation associated with kidneys. Otherwise, these animals showed less abnormalities compared to other nontreated tumor-bearing mice, which was due to the reduced tumor burden [88].

Mechanisms of antitumor effectiveness of $I L-12$ electrogene therapy were addressed in many studies. The antitumor action of IL-12 is multifaceted and involves activation of innate resistance as well as adaptive immunity. Increased local and systemic levels of IL-12 and IFN- $\gamma$ were demonstrated; these levels can be controlled by the dose of the 
plasmid DNA, the route of administration, the parameters of electric pulses and the number of applications. Intratumoral $I L-12$ electrogene therapy induced infiltration of immune cells $\mathrm{CD}^{+} \mathrm{T}$ lymphocytes, active iNOS+ macrophages and $\mathrm{NK}$ cells. Infiltration of immune cells, especially $\mathrm{CD}^{+} \mathrm{T}$ lymphocytes, were absent or much less pronounced after intramuscular therapy. Tumor-specific cytotoxic T lymphocytes (CTL) activity measured in lymphocytes isolated from spleens was higher after intratumoral than after intramuscular IL-12 electrogene therapy. Furthermore, studies performed in nude mice lacking $\mathrm{T}$ lymphocytes demonstrated the main role of $\mathrm{T}$ lymphocytes in tumor eradiation for successful $I L-12$ electrogene therapy. Depletion of $\mathrm{CD}^{+}{ }^{+} \mathrm{T}$ lymphocytes from immunocompetent mice did not affect tumor eradication, while depletion of NK cells partially reversed $I L-12$ electrogene therapy demonstrating an important role of NK cells in the antitumor action of IL-12 [68, 69, 77, 89]. Antiangiogenic effects were also demonstrated for $I L-12$ electrogene therapy. Immunohistological staining of CD31 in tumors following $I L-12$ electrogene therapy demonstrated reduced microvessel density and electron microscopy also revealed apoptosis of endothelial cells $[68,69,77,89,90]$. In addition, the expression of VEGF was decreased in tumors treated by $I L-12$ electrogene therapy. IP-10 and Mig, chemokines that are regulated by IFN- $\gamma$ and are involved in inhibition of angiogenesis, were upregulated in tumors treated by $I L-12$ electrogene therapy [90]. Furthermore, a microarray study showed that Mig, Stat1 and IRF7 were the three genes that were the most altered after $I L-12$ electrogene therapy. IRF7 accumulated in the nuclei upregulated the expression of Mig and Stat1 after intratumoral $I L-12$ electrogene therapy to a larger extent than after intramuscular $I L-12$ electrogene therapy. Additional analysis demonstrated involvement of Mig in induction of $\mathrm{CD}^{+}$and $\mathrm{CD}^{+} \mathrm{T}$ cell infiltration in tumors and that a lack of Stat1 expression inhibited IL-12mediated induction of IP10 [91].

Taken together, the antitumor action of $I L-12$ electrogene therapy is pleotropic and involves different elements, infiltration of effector immune cells and antiangiogenic action. It appears that for complete tumor eradication, which was mainly observed after intratumoral $I L$ - 12 electrogene therapy, tumor infiltration with $\mathrm{CD}^{+} \mathrm{T}$ cells is necessary, while prevention of tumor establishment, growth of distant tumors and metastases, is also regulated by NK cells, a protective B cell response and the antiangiogenic action mediated by IFN$\gamma$ induction of IP10 and Mig (Fig. (1)).

\section{IL-12 ELECTROGENE THERAPY IN COMBINATION WITH OTHER THERAPIES}

Electrogene therapy with $I L-12$ was not curative in certain tumor types when injected intratumorally or in most cases when it was injected into the muscle or into the skin. Therefore, several studies address the possibility of combining $I L-12$ electrogene therapy with other treatments. Some of the studies combined it with electrochemotherapy, which is another method using electroporation that is already in clinical practice with the chemotherapeutic drugs cisplatin and bleomycin. The other studies combined it with other therapeutic genes, and some with standard established cancer treatments, such as radiotherapy.
The combination of electrochemotherapy with bleomycin and electrogene therapy with IL-12 was addressed in two studies. In 2003, treatment effectiveness of intratumoral injection of a mixture of bleomycin with plasmid DNA encoding $I L-12$ followed by application of low voltage electric pulses $(125 \mathrm{~V} / \mathrm{cm}$ voltage over interelectrode distance) of 50 $\mathrm{ms}$ duration was evaluated in B16 melanoma tumors. Significant tumor growth delay and reduction of induced lung metastases with $37.5 \%$ cured mice were observed [92]. Another study was performed in squamous cell carcinoma SCCVII and high-grade malignant mammary 4T1 tumors. Increased antitumor effectiveness was obtained with $60 \%$ of 4T1 mammary tumor cures and $100 \%$ SCCVII tumor cures. In addition, inhibition of metastatic tumor growth and prevention of redevelopment of tumors was also achieved [93]. The authors studied the contribution of single agents (bleomycin or IL-12) to antitumor effectiveness of a combined treatment with both agents. The vascular-disrupting effect was attributed to the action of bleomycin and stimulation of the immune response to IL-12. The vascular effect of electroporation and, specifically, the vascular-disrupting effect of electrochemotherapy with bleomycin are well-known [94], supporting the results obtained by Torrero et al. [93].

Improvement of the therapeutic effectiveness of $I L-12$ electrogene therapy was also achieved by additional treatment of melanoma B16 tumors with $I L-18$ plasmid DNA that was mixed with $I L-12$ plasmid DNA. Repetitive intratumoral treatment (4-times treatment on days $0,2,10,12$ ) with both cytokines resulted in $\sim 70 \%$ tumor cures, while the treatment with $I L-12$ electrogene therapy alone was not curative [40]. Combined intratumoral electrogene therapy with plasmid DNA encoding IL-12 and Herpes simplex virus thymidine kinase was performed in B16 and CT-26 tumor models, combining immunotherapy with the suicide gene. The therapy was repeated twice, four or six times. The number of CT26 tumor cures increased with the increased number of therapy repetitions and reached $91 \%$, when the therapy was repeated 6 times in 2-day intervals. In B16 tumors, 4 times repeated therapy resulted in $92 \%$ growth inhibition [95]. Electrogene therapy combining the costimulatory molecule B7.1, which was shown to activate $\mathrm{CD} 4^{+}$and $\mathrm{CD} 8^{+} \mathrm{T}$ lymphocytes [96], and $I L-12$, was tested in squamous cell carcinoma SCCVII, which lacks B7.1, and the prostate carcinoma TRAMP tumor model. The effect was more pronounced in SCVII tumors with $80 \%$ tumor cures. The cured mice also developed antitumor immunity [97]. A high complete response rate $(100 \%)$ was also obtained in CT-26 tumors treated with a combination of $I L-12$ and $I L-27$ electrogene therapy. This high complete response rate was only obtained when $I L-12$ electrogene therapy was performed 10 days before $I L-27$ electrogene therapy. The response of the highly malignant 4T1 tumor was less pronounced, resulting in $33 \%$ tumor cures [98]. An interesting study was performed on the mouse mammary tumor D2F2 using combined intratumoral electrogene therapy with $I L-12$ and tetanus toxin fragment $C$. This therapy was effective only in mice with depleted regulatory $\mathrm{T}$ lymphocytes (Treg) resulting in $63 \%$ tumor cures, while in mice without depletion, this therapy only had a minor effect on tumor growth. These results are in contradiction with other published reports on $I L-12$ electrogene therapy. The reason for this discrepancy was not addressed by 


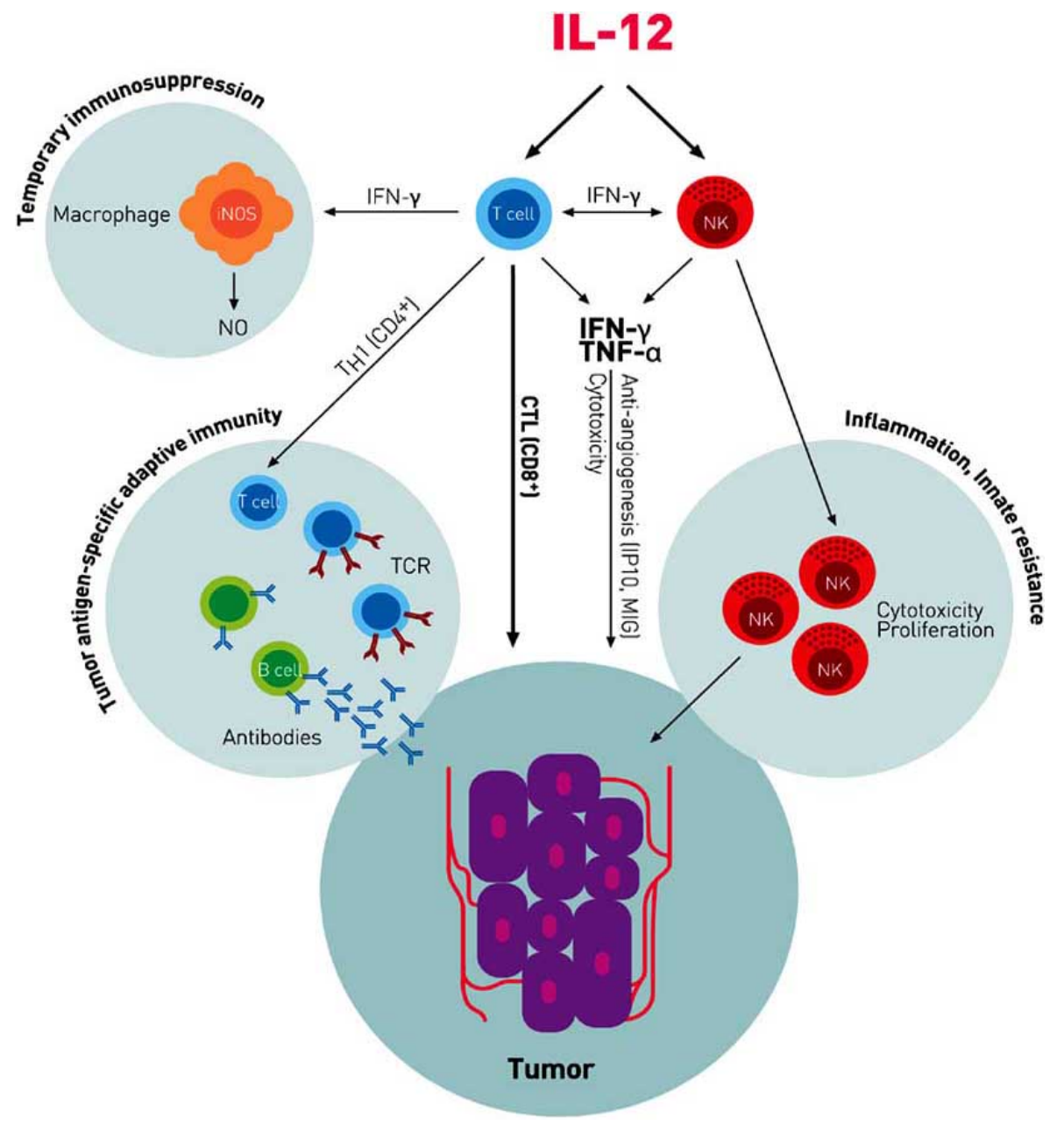

Fig. (1). Mechanisms involved in antitumor effectiveness of IL-12.

the authors and remains to be elucidated [80]. Recently, intratumoral $I L-12$ electrogene therapy combined with small interference RNA (siRNA) targeting microphthalmia-associated transcription factor (Mitf) was evaluated in B16 melanoma [99]. Mitf is a transcription factor regulating various genes associated with the melanin synthesis pathway and malignant transformation of melanocytes into malignant melanoma [100]. Combined treatment with intratumorally injected siRNA duplexes against Mitf $(20 \mu \mathrm{g})$ mixed with $5 \mu \mathrm{g}$ of plasmid DNA encoding $I L-12$ and followed by application of electric pulses to the tumor resulted in pronounced antitumor effectiveness. It was more effective than single treatments with $I L-12$ electrogene therapy alone or siRNA against Mitf alone. However, no tumor cures were obtained [99].

A radiosensitizing effect of recombinant protein IL-12 and local adenoviral gene therapy was indicated when combined with radiotherapy in previous studies [101-105]. To date, only intramuscular electrogene therapy with $I L-12$ was tested in combination with local radiotherapy. Combined treatment was evaluated on established subcutaneous sarcoma tumors SA-1 and LPB and on induced SA-1 lung metastases. $I L-12$ electrogene therapy repeated three times with one tumor irradiation applied $24 \mathrm{~h}$ after the first electrogene therapy resulted in $\sim 45 \%$ SA-1 tumor cures and $100 \%$ LPB tumor cures. The effect on induced lung metastases was also determined. Prophylactic electrogene therapy performed $24 \mathrm{~h}$ before irradiation resulted in almost complete reduction of SA-1 lung metastases. A 1.3 fold dose-modifying factor was determined when electrogene therapy was combined with graded irradiation doses [78].

Results from studies combining $I L-12$ electrogene therapy with other treatments pointed out that boosting the immune response of the organism by IL-12 is very efficient when $I L-12$ electrogene therapy is combined with standard treatments, such as chemotherapy or radiotherapy. These treatments resulted in a high percentage of complete eradication of primary tumors and induced lung metastases also leading to development of antitumor immunity. Combined therapies with other gene therapies were less effective. Further studies on evaluation of toxicities associated with $I L-12$ electrogene therapy combined with standard treatment are warranted to translate these effective treatments into clinical studies.

\section{CLINICAL STUDIES WITH IL-12 ELECTROGENE- THERAPY}

Gene therapy with $I L-12$ showed remarkable antitumor activity in different tumor models at the preclinical level, and has progressed to a number of clinical trials in both human 
and veterinary medicine. In these studies, different delivery methods for $I L-12$ were used: naked plasmid DNA injection, adenoviral and retroviral vector and electroporation $[28,46$, 48, 50-54, 106-108].

In veterinary oncology, three preliminary studies were reported in the congress proceedings [106-108]. Canine mast cell tumors, which are the most common malignant cutaneous tumors in dogs, with extremely variable biological behavior, which can make the proper staging of disease and therefore choice of appropriate therapy very challenging, were treated with intratumoral $I L-12$ electrogene therapy. Eight dogs with 11 cytologically confirmed tumors were included in the study. A good local antitumor effect with significant reduction of treated tumors' size, ranging from $15 \%$ to $83 \%$ (mean $52 \%$ ) of the initial tumor volume was obtained (Fig. (2)). Additionally, a change in the histological structure of treated nodules was seen as reduction in the number of malignant mast cells and inflammatory cell infiltration of treated tumors. Furthermore, systemic release of IL-12 and IFN- $\gamma$ in treated dogs was detected, without any noticeable local or systemic side-effects. Again, the data suggest that intratumoral $I L-12$ electrogene therapy could be used for controlling local as well as systemic disease [107, 108]. In horses, sarcoid represents a spontaneous model of tumor which is frequent in equine oncology and is in many cases a real therapeutic challenge. The combination of electrochemotherapy with intratumoral cisplatin and intratumoral $I L-12$ electrogene therapy was performed in 6 sarcoids with poor prognosis. The clinical response, increased mRNA IFN$\gamma$ levels present in lymphocytes and the presence of $\mathrm{CD}^{+}$ and $\mathrm{CD}^{+} \mathrm{T}$ cells in the immunohistochemically-stained tumor section, demonstrated good antitumor effectiveness of this approach [106].

The first clinical study on $I L-12$ electrogene therapy was published in 2008. A phase I dose escalation study of intratumoral $I L-12$ electrogene therapy was carried out in 24 patients with malignant melanoma subcutaneous metastases.
Patients were treated 3 times on days 1,5 and 8 . The maximum dose of plasmid per tumor nodule was $1.6 \mathrm{mg}$, which resulted in a cumulative dose of 3.8 and $5.8 \mathrm{mg}$ in two patients with multiple nodules. Fine needle aspiration biopsy was performed before, whilst excisional biopsy was performed after the treatment to assess histology of tumors, immune cell infiltration and to determine the levels of IL-12 in tumors. Reponses to treatment were evaluated by the modified Response Evaluation Criteria in Solid Tumors (RECIST). The response to therapy was observed in treated as well as in distant non-treated tumor nodules. In $53 \%$ of patients a systemic response was observed resulting in either stable disease or an objective response. The major adverse side-effect was transient pain after application of electric pulses. In post-treatment biopsies, tumor necrosis and immune cell infiltration was observed. This first human clinical trial with IL-12 electrogene therapy in metastatic melanoma proved that this therapy is safe and effective. It also forms a firm foundation for further clinical evaluation of this approach [46].

\section{CONCLUSIONS}

The literature review demonstrates that many preclinical and clinical studies were done and are still going on in gene therapy of cancer. Although the vast majority of studies were performed with viral vectors, non-viral approaches are gaining interest, due to their safety and simplicity in plasmid preparation. In addition, one of the major advantages of electrogene therapy with $I L-12$ is that it does not result in systemic toxicity. Neither intratumoral nor intramuscular or peritumoral $I L-12$ electrogene therapy resulted in any adverse effects that were previously demonstrated for antitumor treatments with recombinant IL-12 protein or adenoviral approaches. Many of the studies have dealt with $I L-12$ electrogene therapy as a means to target local or systemic disease, because IL-12 is a potent inductor of antigen-specific adaptive immunity and innate resistance. Although clinical

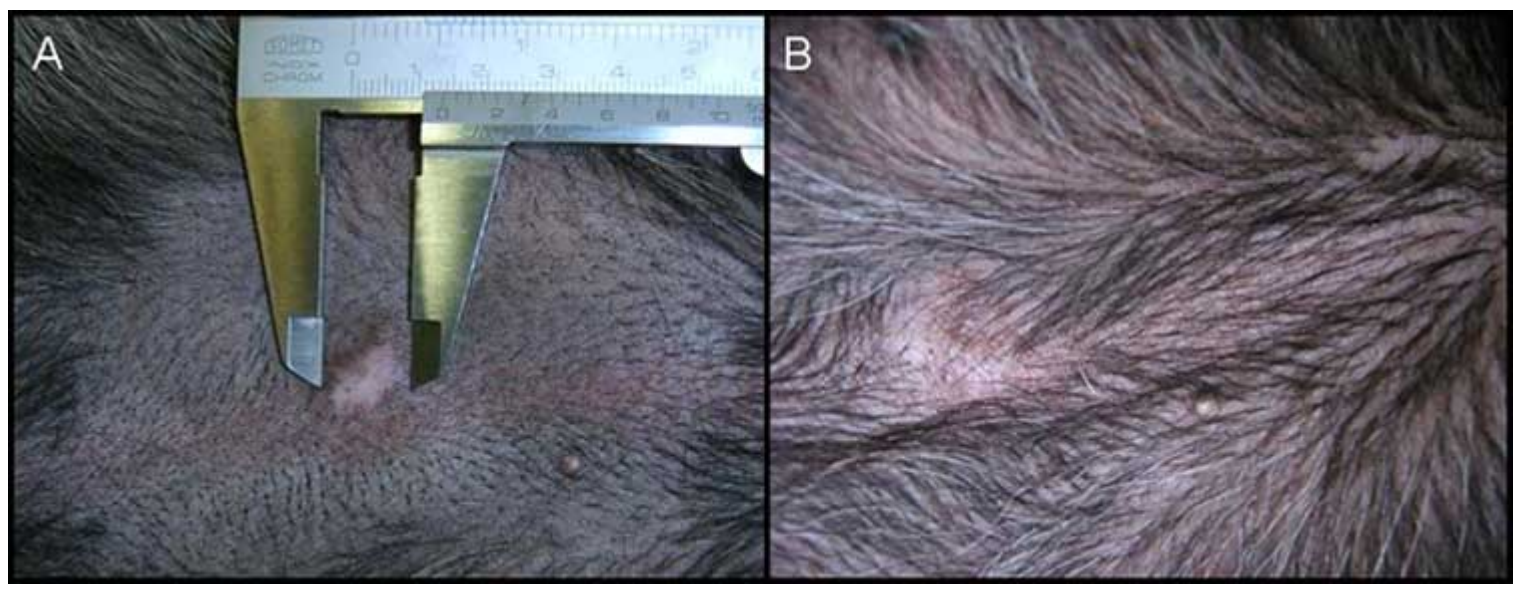

Fig. (2). Pictures of mast cell tumor in dog treated with intratumoral $I L-12$ electrogene therapy. Tumor was located on linea alba. Due to the inconvenient location of tumor for surgical intervention, electrochemotherapy with cisplatin was performed. Initial size of the tumor was 1.9 $\mathrm{x} 1.4 \mathrm{x} 0.7 \mathrm{~cm}$. Electrochemotherapy was performed by intrautmoral injection of $4 \mathrm{mg}$ of cisplatin followed by application of electric pulses. Needle electrodes were used with interelectrode distance $4 \mathrm{~mm}(420 \mathrm{~V}, 100 \mu \mathrm{s})$. One month afer therapy, fine needle aspiration was performed that confimed the presence of residual malignant cells (A). Therefore, intratumoral $I L-12$ electrogene therapy was performed on the remaining tumor nodule. Electrogene therapy consisted of injection of plasmid DNA encoding for IL-12 (1 mg) followed by two application of electric pulses (360 V amplitude, $5 \mathrm{~ms}$ duration, plate electrodes with $6 \mathrm{~mm}$ interelectrode distance,). Tumor was completely eradicated within 1 month $(\mathbf{B})$ and has been currently in complete response for more than 1 year. 
Table 1. Preclinical Studies in Mice of $I L-12$ Electrogene Therapy as a Single Antitumor Treatment

\begin{tabular}{|c|c|c|c|}
\hline Hepatocellular carcinoma & Intratumoral & $\begin{array}{l}\text { Inhibition of growth of treated tumors } \\
\text { Inhibition of growth of distant non-treated tumors } \\
\text { Inhibition of development of lung metastases }\end{array}$ & [68] \\
\hline Squamous cell carcinoma & Intramuscular & $\begin{array}{c}\text { Inhibition of tumor growth } \\
\text { Inhibition of tumor establishment }\end{array}$ & [42] \\
\hline $\begin{array}{l}\text { Melanoma in immunocompe- } \\
\text { tent mice }\end{array}$ & Intratumoral and intramuscular & $\begin{array}{l}47 \% \mathrm{TC}^{1} \text { after intratumoral therapy } \\
\text { No } \mathrm{TC} \text { after intramuscular } \\
71 \% \text { mice resistant to rechallenge }\end{array}$ & [69] \\
\hline Melanoma in nude mice & intratumoral & $\begin{array}{c}\text { No TC } \\
\text { Importance of immune system demonstrated }\end{array}$ & [69] \\
\hline Melanoma & 2 times intramuscular & Inhibition of development of induced lung metastases & [74] \\
\hline Colon carcinoma & 3 or 7 times intratumoral & $\begin{array}{l}80 \% \text { TC after } 7 \text {-times repeated therapy } \\
\text { Development of antitumor immunity }\end{array}$ & [75] \\
\hline Renal carcinoma & 2 times intratumoral & Inhibition of tumor growth & [75] \\
\hline Melanoma $(<3 \mathrm{~mm})$ & intramuscular & No TC & [76] \\
\hline Colon carcinoma $(<3 \mathrm{~mm})$ & intramuscular & $55 \% \mathrm{TC}$ & [76] \\
\hline Lymphoma $(<3 \mathrm{~mm})$ & intramuscular & $70 \% \mathrm{TC}$ & [76] \\
\hline Sarcoma & peritumoral & $16 \% \mathrm{TC}$ & [79] \\
\hline
\end{tabular}

${ }^{1} \mathrm{TC}=$ tumor cures

Table 2. Preclinical Studies in Mice of $I L-12$ Electrogene Therapy in Combination with Other Treatment Modalities for Treatment of Tumors

\begin{tabular}{|c|c|c|c|}
\hline Tumor Type & Type of Therapy & Treatment Outcome & Reference \\
\hline \hline Melanoma & Intratumoral $I L-12+$ bleomycin & $\begin{array}{c}37.5 \% \mathrm{TC}^{1} \\
\text { Inhibition of growth of lung metastases }\end{array}$ & $\begin{array}{c}\text { 80\% TC } \\
\text { Inhibition of growth of lung metastases } \\
\text { 40\% mice resistant to rechallenge }\end{array}$ \\
\hline Squamous cell carcinoma & Intratumoral $I L-12+$ bleomycin & $\begin{array}{c}60 \% \mathrm{TC} \\
\text { [nhibition of growth of lung metastases }\end{array}$ \\
\hline Mammary carcinoma & $\begin{array}{c}\text { 2-times intratumoral } I L-12+ \\
\text { bleomycin }\end{array}$ & 70\% TC \\
\hline Melanoma & $\begin{array}{c}\text { 4-times Intratumoral } I L-12+ \\
\text { intratumoral } I L-18\end{array}$ & {$[93]$} \\
\hline
\end{tabular}


(Table 2) contd......

\begin{tabular}{|c|c|c|c|}
\hline Tumor Type & Type of Therapy & Treatment Outcome & Reference \\
\hline Melanoma & $\begin{array}{c}2,4 \text { and 6-times intratumoral } I L \text { - } \\
12+\text { Herpes virus thymidine } \\
\text { kinase }\end{array}$ & Inhibition of tumor growth after 4-times repeated therapy & [95] \\
\hline Colon carcinoma & $\begin{array}{c}2,4 \text { and 6-times intratumoral } I L \text { - } \\
12+\text { Herpes virus thymidine } \\
\text { kinase }\end{array}$ & $91 \%$ TC after 6-times repeated therapy & [95] \\
\hline Squamous cell carcinoma & Intratumoral $I L-12+\mathrm{B} 7.1$ & $\begin{array}{c}80 \% \mathrm{TC} \\
75 \% \text { mice resistant to rechallenge }\end{array}$ & [97] \\
\hline Prostate carcinoma & Intraumoral $I L-12+\mathrm{B} 7.1$ & No TC, inhibition of tumor growth & [97] \\
\hline Colon carcinoma & Intratumoral $I L-12+I L-27$ & $100 \% \mathrm{TC}$ & [98] \\
\hline Mammary carcinoma & Intratumoral $I L-12+I L-27$ & $33 \% \mathrm{TC}$ & [98] \\
\hline Mammary carcinoma & $\begin{array}{l}\text { Intratumoral } I L-12+\text { tetanus } \\
\text { toxin fragment } \mathrm{C}\end{array}$ & $63 \% \mathrm{TC}$ in Treg depleted mice & [80] \\
\hline Melanoma & $\begin{array}{c}\text { Intratumoral } I L-12+\text { siRNA } \\
\text { against Mift }\end{array}$ & No TC, inhibition of tumor growth & [100] \\
\hline Sarcoma & $\begin{array}{c}\text { Intramuscular } I L-12+\text { radiother- } \\
\text { apy }\end{array}$ & $45-100 \% \mathrm{TC}$ & [78] \\
\hline
\end{tabular}

${ }^{1} \mathrm{TC}=$ tumor cures.

studies with recombinant IL-12 were a disappointment, gene therapy with $I L-12$, due to its controlled release and lower toxicity, has gained a lot of interest and has the potential to be translated into the clinic.

The studies have demonstrated that $I L-12$ gene electrotransfer is as effective approach as local treatment by intratumoral gene electrotransfer, or as systemic treatment by muscle gene electrotransfer. Furthermore, peritumoral treatment has also shown both local and systemic effects. All these approaches can target accessible tumor nodules by a direct intratumoral approach or disseminated disease in the case of intramuscular gene electrotransfer. Due to the still limited effectiveness of $I L-12$ gene electrotherapy, combined approaches with established treatments such as radiotherapy, electrochemotherapy were performed. Synergistic or additive effects were observed.

Antitumor effectiveness, local and loco-regional, of intratumoral $I L-12$ gene electrotransfer was already demonstrated in a clinical trial on melanoma metastases. The first studies are also being undergone in veterinary oncology, supporting the clinical experience in human medicine and demonstrating that $I L-12$ electrogene therapy can be successfully used in the treatment of primary tumors and metastases in dogs and horses.

\section{ACKNOWLEDGEMENTS}

The authors acknowledge the financial support of the state budget by Slovenian Research Agency (P3-0003 (MC and GS), J3-2277 (MC and GS) and P2-0249 (TJ)).

\section{REFERENCES}

[1] Trinchieri G. Interleukin-12 and the regulation of innate resistance and adaptive immunity. Nat Rev Immun 2003; 3: 133-46.
[2] Kobayashi M, Fitz L, Ryan M, et al. Identification and purification of natural-killer cell stimulatory factor (NKSF), a cytokine with multiple biologic effects on human-lymphocytes. J Exp Med 1989; $170: 827-45$.

[3] Stern AS, Podlaski FJ, Hulmes JD, et al. Purification to homogeneity and partial characterization of cytotoxic lymphocite maturation factor from human B-lymphoblastoid cells. Proc Natl Acad Sci USA 1990; 87: 6808-12.

[4] Gubler U, Chua AO, Schoenhaut DS, et al. Coexpression of 2distinct genes is required to generate secreted bioactive cytolytic lyphocyte maturation factor. Proc Natl Acad Sci USA 1991; 88: 4143-7.

[5] Wolf SF, Temple PA, Kobayashi M, et al. Cloning of the cDNA for natural-killer-cell stimulatory factor, a heterodimeric cytokine with multiple biological effects on T-cells and natural-killer-cells. J Immunol 1991; 146: 3074-81.

[6] Schoenhaut DS, Chua AO, Wolitzky AG, et al. Cloning and expression of murine IL-12. J Immunol 1992; 148: 3433-40.

[7] Brunda MJ, Luistro L, Warrier RR, et al. Antitumor and antimetastatic activity of interleukin-12 against murine tumors. J Exp Med 1993; 178: 1223-30.

[8] Del Vecchio M, Bajetta E, Canova S, et al. Interleukin-12: Biological properties and clinical application. Clin Cancer Res 2007; 13: 4677-85.

[9] Lamont AG, Adorini L. IL-12: a key cytokine in immune regulation. Immunol Today 1996; 17: 214-7.

[10] Lotze MT, Zitvogel L, Campbell R, et al. Cytokine gene therapy of cancer using interleukin-12: murine and clinical trials. In: Lotze MT, Trinchieri G, Gately M, Wolf S, Eds. Inerleukin 12: cellular and molecular immunology of an important regulatory. Cytokine. New York: Annals of the New York Academy of Science 1996; Vol. 795, pp. 440-54.

[11] Sangro B, Melero I, Qian C, Prieto J. Gene therapy of cancer based on interleukin 12. Curr Gene Ther 2005; 5: 573-81.

[12] Tahara H, Zitvogel L, Storkus WJ, Robbins PD, Lotze MT. Murine models of cancer cytokine gene therapy using interleukin-12. In: Lotze MT, Trinchieri G, Gately M, Wolf S, Eds. Inerleukin 12: Cellular and molecular immunology of an important regulatory cytokine. New York: Annals of the New York Academy of Science 1996; Vol. 795, pp. 275-83. 
[13] Voest EE, Kenyon BB, Oreilly MS, Truitt G, Damato RJ, Folkman J. Inhibition of angiogenesis in-vivo by interleuki-12. J Natl Cancer Inst 1995; 87: 581-6.

[14] Zitvogel L, Robbins PD, Storkus WJ, et al. Interleukin-12 and B7.1 co-stimulation cooperate in the induction of effective antitumor immunity and therapy of established tumors. Eur J Immunol 1996; 26: 1335-41.

[15] Lotze MT, Zeh HJ, Elder EM, et al. Use of T-cell-growth-factors (interleukin-2, interleukin-4, interleukin-7, interleukin-10 and interleukin-12 in the evaluation of T-cell reactivity to melanoma. J Immunother 1992; 12: 212-7.

[16] Leder GH, Oppenheim M, Rosenstein M, Lotze MT, Berger HG. Addition of interleukin-12 to low dose of interleukin-2 treatment improves antitumor efficacy in-vivo. Z Gastroenter 1995; 33: 499502 .

[17] Colombo MP, Trinchieri G. Interleukin-12 in anti-tumor immunity and immunotherapy. Cytokine Growth Factor Rev 2002; 13: 15568.

[18] Atkins MB, Robertson MJ, Gordon M, et al. Phase I evaluation of intravenous recombinant human interleukin 12 in patients with advanced malignancies. Clin Cancer Res 1997; 3: 409-17.

[19] Gollob JA, Mier JW, Veenstra K, et al. Phase I trial of twiceweekly intravenous interleukin 12 in patients with metastatic renal cell cancer or malignant melanoma: Ability to maintain IFNgamma induction is associated with clinical response. Clin Cancer Res 2000; 6: 1678-92.

[20] Lenzi R, Kudelka A, Verschraegen C, et al. Intraperitoneal administration of human recombinant interleukin-12 (rhIL-12) for the treatment of ovarian and GI cancer patients with progressive disease after standard chemotherapy (T97-0034). Clin Cancer Res 1999; 5: 380.

[21] Lenzi R, Edwards R, June C, et al. Phase II study of intraperitoneal recombinant interleukin-12 (rhIL-12) in patients with peritoneal carcinomatosis (residual disease \& $1 \mathrm{t} ; 1 \mathrm{~cm}$ ) associated with ovarian cancer or primary peritoneal carcinoma. J Transl Med 2007; 5: 66.

[22] Motzer RJ, Rakhit A, Schwartz LH, et al. Phase I trial of subcutaneous recombinant human interleukin-12 in patients with advanced renal cell carcinoma. Clin Cancer Res 1998; 4: 1183-91.

[23] Robertson MJ, Cameron C, Atkins MB, et al. Immunological effects of interleukin 12 administered by bolus intravenous injection to patients with cancer. Clin Cancer Res 1999; 5: 9-16.

[24] Younes A, Pro B, Robertson MJ, et al. Phase II clinical trial of interleukin-12 in patients with relapsed and refractory nonHodgkin's lymphoma and Hodgkin's disease. Clin Cancer Res 2004; 10: 5432-8

[25] Rook AH, Wood GS, Yoo EK, et al. Interleukin-12 therapy of cutaneous T-cell lymphoma induces lesion regression and cytotoxic T-cell responses. Blood 1999; 94: 902-8.

[26] Leonard JP, Sherman ML, Fisher GL, et al. Effects of single-dose interleukin-12 exposure on interleukin-12-associated toxicity and interferon-gamma production. Blood 1997; 90: 2541-8.

[27] Schultz J, Pavlovic J, Strack B, Nawrath M, Moelling K. Longlasting anti-metastatic efficiency of interleukin 12-encoding plasmid DNA. Hum Gene Ther 1999; 10: 407-17.

[28] Heinzerling LM, Feige K, Rieder S, et al. Tumor regression induced by intratumoral injection of DNA coding for human interleukin 12 into melanoma metastases in gray horses. J Mol Med 2001; 78: 692-702.

[29] Bramson JL, Hitt M, Addison CL, et al. Direct intratumoral injection of an adenovirus expressing interleukin-12 induces regression and long-lasting immunity that is associated with highly localized expression of interleukin-12. Hum Gene Ther 1996; 7: 1995-2002.

[30] Caruso M, Pham-Nguyen K, Kwong YL, et al. Adenovirus-mediated interleukin-12 gene therapy for metastatic colon carcinoma. Proc Natl Acad Sci USA 1996; 93: 11302-6.

[31] Hirschowitz EA, Crystal RG. Adenovirus-mediated expression of interleukin-12 induces natural killer cell activity and complements adenovirus-directed gp75 treatment of melanoma lung metastases. Am J Res Cell Mol 1999; 20: 935-41.

[32] Nasu Y, Bangma CH, Hull GW, et al. Adenovirus-mediated interleukin-12 gene therapy for prostate cancer: suppression of orthotopic tumor growth and pre-established lung metastases in an orthotopic model. Gene Ther 1999; 6: 338-49.

[33] Barajas M, Mazzolini G, Genove G, Bilbao R, Narvaiza I, Schimitz V, Sangro B, Melero I, Qian C, Prieto J. Gene therapy of orthotopic hepatocellular carcinoma in rats using adenovirus coding for interleukin 12. Hepatology 2001; 33(1): 52-61.

[34] Hawley RG, Lieu FHL, Fong AZC, Goldman SJ, Leonard JP, Hawley TS. Retroviral vectors for production of interleukin-12 in the bone marrow to induce a graft-versus-leukemia effect. In: Lotze MT, Trinchieri G, Gately M, Wolf S, Eds. Inerleukin 12: Cellular and Molecular Immunology of an Important Regulatory Cytokine. New York: Annals of the New York Academy of Science 1996; Vol. 795, pp. 341-5.

[35] Puisieux I, Odin L, Poujol D, et al. Canarypox virus-mediated interleukin 12 gene transfer into murine mammary adenocarcinoma induces tumor suppression and long-term antitumoral immunity. Hum Gene Ther 1998; 9: 2481-92.

[36] Asselin-Paturel C, Lassau N, Guinebretiere JM, et al. Transfer of the murine interleukin-12 gene in vivo by a Semliki Forest virus vector induces B16 tumor regression through inhibition of tumor blood vessel formation monitored by Doppler ultrasonography. Gene Ther 1999; 6: 606-15.

[37] Rakhmilevich AL, Timmins JG, Janssen K, et al. Gene gunmediated IL-12 gene therapy induces antitumor effects in the absence of toxicity: A direct comparison with systemic IL-12 protein therapy. J Immunother 1999; 22: 135-44.

[38] Rakhmilevich AL, Janssen K, Turner J, Culp J, Yang NS. Cytokine gene therapy of cancer using gene gun technology: Superior antitumor activity of interleukin-12. Hum Gene Ther 1997; 8 : 1303-11.

[39] Heller R, Schultz J, Lucas ML, et al. Intradermal delivery of interleukin-12 plasmid DNA by in vivo electroporation. DNA Cell Biol 2001; 20: 21-26.

[40] Kishida T, Asada H, Satoh E, et al. In vivo electroporationmediated transfer of interleukin-12 and interleukin-18 genes induces significant antitumor effects against melanoma in mice. Gene Ther 2001; 8: 1234-40.

[41] Lohr F, Lo DY, Zaharoff DA, et al. Effective tumor therapy with plasmid-encoded cytokines combined with in vivo electroporation. Cancer Res 2001; 61: 3281-4.

[42] Hanna E, Zhang XJ, Woodlis J, et al. Intramuscular electroporation delivery of IL-12 gene for treatment of squamous cell carcinoma located at distant site. Cancer Gene Ther 2001; 8: 151-7.

[43] Blezinger $\mathrm{P}$, Freimark $\mathrm{BD}$, Matar $\mathrm{M}$, et al. Intratracheal administration of interleukin 12 plasmid-cationic lipid complexes inhibits murine lung metastases. Hum Gene Ther 1999; 10: 723-31.

[44] Jia SF, Worth LL, Densmore CL, Xu B, Zhou ZC, Kleinerman ES. Eradication of osteosarcoma lung metastases following intranasal interleukin-12 gene therapy using a nonviral polyethylenimine vector. Cancer Gene Ther 2002; 9: 260-6.

[45] Alves A, Vibert E, Trajcevski S, et al. Adjuvant interleukin-12 gene therapy for the management of colorectal liver metastases. Cancer Gene Ther 2004; 11: 782-9.

[46] Daud AI, DeConti RC, Andrews S, et al. Phase I trial of interleukin-12 plasmid electroporation in patients with metastatic melanoma. J Clin Oncol 2008; 26: 5896-903.

[47] Heinzerling L, Burg G, Dummer R, et al. Intratumoral injection of DNA encoding human interleukin 12 into patients with metastatic melanoma: Clinical efficacy. Hum Gene Ther 2005; 16: 35-48.

[48] Kang WK, Park C, Yoon HL, et al. Interleukin 12 gene therapy of cancer by peritumoral injection of transduced autologous fibroblasts: Outcome of a phase I study. Hum Gene Ther 2001; 12 671-84.

[49] Mahvi DM, Henry MB, Albertini MR, et al. Intratumoral injection of IL-12 plasmid DNA - results of a phase I/IB clinical trial Cancer Gene Ther 2007; 14: 717-23.

[50] Mazzolini G, Alfaro C, Sangro B, et al. Intratumoral injection of dendritic cells engineered to secrete interleukin-12 by adenovirus in patients with primary and secondary liver cancer. J Hepatol 2005 42:256

[51] Ren H, Boulikas T, Soling A, Warnke PC, Rainov NG Immunogene therapy of recurrent glioblastoma multiforme with a liposomally encapsulated replication-incompetent Semliki forest virus vector carrying the human interleukin-12 gene - a phase I/II clinical protocol. J Neurooncol 2003; 64: 147-54.

[52] Sangro B, Mazzolini G, Ruiz J, et al. Phase I trial of intratumoral injection of an adenovirus encoding interleukin-12 for advanced digestive tumors. J Clin Oncol 2004; 22: 1389-97.

[53] Siddiqui F, Avery PR, LaRue SM, et al. A phase I hyperthermiainduced interleukin-12 gene-therapy trial in a spontaneously arising 
feline soft tissue sarcoma model. Int J Radiat Oncol Biol Phys 2004; 60: 2403.

[54] Siddiqui F, Li CY, Larue SM, et al. A phase I trial of hyperthermia-induced interleukin-12 gene therapy in spontaneously arising feline soft tissue sarcomas. Mol Cancer Ther 2007; 6: 3809.

[55] Triozzi PL, Strong TV, Bucy RP, et al. Intratumoral administration of a recombinant canarypox virus expressing interleukin 12 in patients with metastatic melanoma. Hum Gene Ther 2005; 16: 91100.

[56] Weiss JM, Subleski JJ, Wigginton JM, Wiltrout RH. Immunotherapy of cancer by IL-12-based cytokine combinations. Expert Opin Biol Ther 2007; 7: 1705-21.

[57] Cocco C, Pistoia V, Airoldi I. New Perspectives for melanoma immunotherapy: role of IL-12. Curr Mol Med 2009; 9: 459-69.

[58] Cemazar M, Golzio M, Sersa G, Rols MP, Teissie J. Electricallyassisted nucleic acids delivery to tissues in vivo: where do we stand? Curr Pharm Des 2006; 12: 3817-25.

[59] Cemazar M, Sersa G. Electrotransfer of therapeutic molecules into tissues. Curr Opin Mol Ther 2007; 9: 554-62.

[60] Favard C, Dean DS, Rols MP. Electrotransfer as a non viral method of gene delivery. Curr Gene Ther 2007; 7: 67-77.

[61] Mir LM. Nucleic acids electrotransfer-based gene therapy (electrogenetherapy): past, current, and future. Mol Biotechnol 2009; 43: 167-76.

[62] Bodles-Brakhop AM, Heller R, Draghia-Akli R. Electroporation for the Delivery of DNA-based Vaccines and Immunotherapeutics: Current Clinical Developments. Mol Ther 2009; 17: 585-92.

[63] Neumann E, Schaeferridder M, Wang Y, Hofschneider PH. Gene transfer into mouse lypoma cellls by electroporation in high lelectric fields. EMBO J 1982; 1: 841-5.

[64] Titomirov AV, Sukharev S, Kistanova E. In vivo electroporation and stable transformation of skin cells of newborn mice by plasmid DNA. Biochim Biophys Acta 1991; 1088: 131-4.

[65] Niu GL, Heller R, Catlett-Falcone R, et al. Gene therapy with dominant-negative Stat3 suppresses growth of the murine melanoma B16 tumor in vivo. Cancer Res 1999; 59: 5059-63.

[66] Chen Z, Kadowaki S, Hagiwara Y, et al. Cross-protection against a lethal influenza virus infection by DNA vaccine to neuraminidase. Vaccine 2000; 18: 3214-22.

[67] Lucas ML, Heller R. Immunomodulation by electrically enhanced delivery of plasmid DNA encoding IL-12 to murine skeletal muscle. Mol Ther 2001; 3: 47-53.

[68] Yamashita Y, Shimada M, Hasegawa H, et al. Electroporationmediated interleukin-12 gene therapy for hepatocellular carcinoma in the mice model. Cancer Res 2001; 61: 1005-12.

[69] Lucas ML, Heller L, Coppola D, Heller R. IL-12 plasmid delivery by in vivo electroporation for the successful treatment of established subcutaneous B16.F10 melanoma. Mol Ther 2002; 5: 668-75.

[70] Kamensek U, Sersa G, Vidic S, Tevz G, Cemazar M. Irradiation, cisplatin and 5-azacytidine up-regulate cytomegalovirus promoter in tumors and muscles: implementation of noninvasive fluorescence imaging. Mol Imaging Biol 2010; [Epub ahead of Print].

[71] Alexopoulou AN, Couchman JR, Whiteford JR. The CMV early enhancer/chicken beta actin (CAG) promoter can be used to drive transgene expression during the differentiation of murine embryonic stem cells into vascular progenitors. BMC Cell Biol 2008; $1: 9$.

[72] Cemazar M, Golzio M, Sersa G, et al. Control by pulse parameters of DNA electrotransfer into solid tumors in mice. Gene Ther 2009; 16: 635-44.

[73] Mesojednik S, Pavlin D, Sersa G, et al. The effect of the histological properties of tumors on transfection efficiency of electrically assisted gene delivery to solid tumors in mice. Gene Ther 2007; 14: 1261-9.

[74] Lucas ML, Heller R. IL-12 gene therapy using an electrically mediated nonviral approach reduces metastatic growth of melanoma. DNA Cell Biol 2003; 22: 755-63.

[75] Tamura $\mathrm{T}$, Nishi $\mathrm{T}$, Goto $\mathrm{T}$, et al. Intratumoral delivery of interleukin 12 expression plasmids with in vivo electroporation is effective for colon and renal cancer. Hum Gene Ther 2001; 12: 1265-76.

[76] Lee SC, Wu CJ, Wu PY, Huang YL, Wu CW, Tao MH. Inhibition of established subcutaneous and metastatic murine tumors by intramuscular electroporation of the interleukin-12 gene. J Biomed Sci 2003; 10: 73-86

[77] Shibata MA, Ito Y, Morimoto J, et al. In vivo electrogene transfer of interleukin-12 inhibits tumor growth and lymph node and tung metastases in mouse mammary carcinomas. J Gene Med 2006; 8 : 335-52.

[78] Tevz G, Kranjc S, Cemazar M, et al. Controlled systemic release of interleukin-12 after gene electrotransfer to muscle for cancer gene therapy alone or in combination with ionizing radiation in murine sarcomas. J Gene Med 2009; 11: 1125-37.

[79] Pavlin D, Cemazar M, Kamensek U, et al. Local and systemic antitumor effect of intratumoral and peritumoral IL-12 electrogene therapy on murine sarcoma. Cancer Biol Ther 2009; 8: 2112-20.

[80] Radkevich-Brown O, Piechocki MP, Back JB, et al. Intratumoral DNA electroporation induces anti-tumor immunity and tumor regression. Cancer Immunol Immunother 2010; 59: 409-17.

[81] Gambotto A, Tuting T, McVey DL, et al. Induction of antitumor immunity by direct intratumoral injection of a recombinant adenovirus vector expressing interleukin-12. Cancer Gene Ther 1999; 6: 45-53.

[82] Gao JQ, Sugita T, Kanagawa N, et al. A single intratumoral injection of a fiber-mutant adenoviral vector encoding interleukin 12 induces remarkable anti-tumor and anti-metastatic activity in mice with Meth-A fibrosarcoma. Biochem Biophys Res Commun 2005; 328: 1043-50.

[83] Havell EA, Fiers W, North RJ. The antitumor function of the tumor necrosis factor (TNF). 1. Therapeutic action of TNF against an established murine sarcoma is indirect, immunologically dependent, and limited by severe toxicity. J Exp Med 1988; 167: 1067-85.

[84] Andre FM, Gehl J, Sersa G, et al. Efficiency of high- and lowvoltage pulse combinations for gene electrotransfer in muscle, liver, tumor, and skin. Hum Gene Ther 2008; 19: 1261-71.

[85] Tevz G, Pavlin D, Kamensek U, et al. Gene electrotransfer into murine skeletal muscle: a systematic analysis of parameters for long-term gene expression. Technol Cancer Res Treat 2008; 7: 91101 .

[86] Pavlin D, Tozon N, Sersa G, Pogacnik A, Cemazar M. Efficient electrotransfection into canine muscle. Technol Cancer Res Treat 2008; 7: 45-54

[87] Chuang TF, Lee SC, Liao KW, et al. Electroporation-mediated IL 12 gene therapy in a transplantable canine cancer model. Int $\mathrm{J}$ Cancer 2009; 125: 698-707.

[88] Heller L, Merkler K, Westover J, et al. Evaluation of toxicity following electrically mediated interleukin- 12 gene delivery in a B16 mouse melanoma model. Clin Cancer Res 2006; 12: 3177-83.

[89] Li SL, Zhang LJ, Torrero M, Cannon M, Barret R. Administration route- and immune cell activation-dependent tumor eradication by IL12 electrotransfer. Mol Ther 2005; 12: 942-9.

[90] Li SL, Zhang XJ, Xia XQ. Regression of tumor growth and induction of long-term antitumor memory by interleukin 12 electrogene therapy. J Natl Cancer Inst 2002; 94: 762-8.

[91] Li SL, Xia XQ, Mellieon FM, Liu JG, Steele S. Candidate genes associated with tumor regression mediated by intratumoral II-12 electroporation gene therapy. Mol Ther 2004; 9: 347-54.

[92] Kishida T, Asada H, Itokawa Y, et al. Electrochemo-gene therapy of cancer: Intratumoral delivery of interleukin-12 gene and bleomycin synergistically induced therapeutic immunity and suppressed subcutaneous and metastatic melanomas in mice. Mol Ther 2003; 8: 738-45.

[93] Torrero MN, Henk WG, Li SL. Regression of high-grade malignancy in mice by bleomycin and interleukin-12 electrochemogenetherapy. Clin Cancer Res 2006; 12: 257-63.

[94] Sersa G, Jarm T, Kotnik T, et al. Vascular disrupting action of electroporation and electrochemotherapy with bleomycin in murine sarcoma. Brit J Cancer 2008; 98: 388-98.

[95] Goto T, Nishi T, Kobayashi O, et al. Combination electro-gene therapy using herpes virus thymidine kinase and interleukin-12 expression plasmids is highly efficient against murine carcinomas in vivo. Mol Ther 2004; 10: 929-37.

[96] Schwartz RH. Costimulation of lypmhocytes-T - The role of CD28, CTLA-4, and B7/BB1 in interleukin-2 production and immunotherapy. Cell 1992; 71: 1065-8.

[97] Liu JG, Xia XQ, Torrero M, et al. The mechanism of exogenous B7.1-enhanced IL-12-mediated complete regression of tumors by a single electroporation delivery. Int J Cancer 2006; 119: 2113-8. 
[98] Zhu S, Lee D, Li S. IL-12 and IL-27 Sequential gene therapy via intramuscular electroporation delivery for eliminating distal aggressive tumors. J Immunol 2010; doi: 10.4049/jimmunol.0902371.

[99] Nakai N, Kishida T, Hartmann G, et al. Mitf silencing cooperates with IL-12 gene transfer to inhibit melanoma in mice. Int Immunopharm 2010; doi:10.1016/j.intimp.2009.12.105.

[100] Davis IJ, Fisher DE. MiT transcription factor associated malignancies in man. Cell Cycle 2007; 6: 1724-9.

[101] Fujita T, Timme TL, Tabata K, et al. Cooperative effects of adenoviral vector-mediated interleukin 12 gene therapy with radiotherapy in a preclinical model of metastatic prostate cancer. Gene Ther 2007; 14: 227-36.

[102] Jin GH, Jin SZ, Liu Y, et al. Therapeutic effect of gene-therapy in combination with local $\mathrm{X}$-irradiation in a mouse malignant melanoma model. Biochem Biophys Res Commun 2005; 330: 97581

[103] Lohr F, Hu K, Haroon Z, et al. Combination treatment of murine tumors by adenovirus-mediated local B7/IL12 immunotherapy and radiotherapy. Mol Ther 2000; 2: 195-203.

Received: February 12, 2010

Revised: May 31, 2010

Accepted: June 04, 2010
[104] Seetharam S, Staba MJ, Schumm LP, et al. Enhanced eradication of local and distant tumors by genetically produced interleukin-12 and radiation. Int J Oncol 1999; 15: 769-73.

[105] Yang Y, Liu SZ, Fu SB. Anti-tumor effects of pNEgr-mIL-12 recombinant plasmid induced by $\mathrm{X}$-irradiation and its mechanisms. Biomed Environ Sci 2004; 17: 135-43

[106] Tamzali Y, Couderc B, Rols MP, Golzio M, Teissie J. Equine cutaneous tumors treatment by electro-chemo-immuno-therapy. Proceeding of the $11^{\text {th }}$ Medicon; IFBME, Spinger: New York, USA, 2007.

[107] Tozon N, Pavlin D, Sersa G, Coer A, Cemazar M. Effectiveness of IL-12 on mast cell tumours in dogs: case report. Proceeding of the $16^{\text {th }}$ ECVIM-CA congress. ECVIM: Amsterdam, Netherlands, September 2006.

[108] Tozon N, Pavlin D, Coer A, Pogačnik A, Sersa, G, Cemazar M, Eds. Intratumoral electrogene therapy of mast cell tumors in dogs. $19^{\text {th }}$ ECVIM - CA Congress. ECVIM: Porto, Portugal 2009. 